\title{
Relationships between Electrophoretic Patterns of Esterases from Salmonella
}

\author{
By PH. GOULLET \\ Laboratoire de Microbiologie, Faculté de Médecine Xavier-Bichat, \\ Université Paris VII, Institut Biomédical des Cordeliers, \\ 2 I, rue de l'École de Médecine, 75270 Paris Cedex 06, France
}

(Received 22 June 1976; revised 6 August 1976)

\section{SUMMAR Y}

Esterases of 85 strains of the four biochemically-defined subgenera of Salmonella, when analysed by the acrylamide-agarose zymogram technique using several synthetic substrates, gave four principal bands $\left(\mathrm{E}_{1}, \mathrm{E}_{2}, \mathrm{E}_{3}, \mathrm{E}_{4}\right)$ and two minor ones. The $E_{1}$ esterase band hydrolysed $\alpha$-naphthyl acetate, whereas the $E_{2}$ band hydrolysed $\beta$-naphthyl acetate. These bands were resistant to di-isofluoropropyl phosphate (DFP) and their electrophoretic distribution among the strains occurred within a relatively small $M_{F}$ range, $M_{F}$ being the distance moved by the esterase band as a percentage of the distance moved by the dye front. The $\mathrm{E}_{3}$ band hydrolysed $\alpha$-naphthyl acetate and $\alpha$-naphthyl butyrate and, to a lesser degree, $\beta$ naphthyl esters, whereas the $\mathrm{E}_{4}$ band hydrolysed $\alpha$-naphthyl acetate. These bands were sensitive to DFP and their electrophoretic distribution among the strains occurred in a wide $M_{F}$ range. All Salmonella strains were closely related in terms of their esterase profiles. However, the divergences in electrophoretic distribution of bands $E_{3}$ and $E_{4}$ were sufficient to recognize the subgenera of most of the Salmonella strains analysed.

\section{INTRODUCTION}

Several esterases that differed in their activity towards naphthyl esters, sensitivity to heat, sensitivity to di-isofluoropropyl phosphate (DFP) and electrophoretic mobility were found in Escherichia coli (Goullet, 1973). Differential esterase patterns were subsequently reported for species of Proteus and Providencia (Goullet, 1975) and for Levinea amalonatica, L. malonatica and Citrobacter (Goullet \& Richard, 1977). For further investigations into the esterases of enterobacteria, the genus Salmonella was chosen because, despite much bacteriological data, the speciation within this composite group remains debatable (Kauffmann, 1963, 1965, 1975; Le Minor, Rhode \& Taylor, 1970; Ewing, 1972; Bascomb et al., 1973; Le Minor \& Rhode, I974; Johnson et al., I975; Véron \& Le Minor, 1975).

This paper reports the characterization and distribution of esterase bands (EC. 3.I.I . ) in the four biochemical clusters of Salmonella, designated as subgenera by Kauffmann (1963, 1965) and proposed as species by Le Minor et al. (1970).

\section{METHODS}

The strains used, kindly provided by C. Richard (Institut Pasteur, Paris, France), are listed in Table $\mathrm{r}$.

Growth conditions, preparation of extracts, heat denaturation, inhibition by DFP, 
Table I. Salmonella species examined

\begin{tabular}{|c|c|c|c|c|c|}
\hline Code & Organism & Serotype & $\begin{array}{c}\text { Strain } \\
\text { designation* }\end{array}$ & Origint, place and date & $\begin{array}{r}\text { Growth } \\
\text { conditions }\end{array}$ \\
\hline \multicolumn{6}{|c|}{ Subgenus I (S. kauffmannii group)§ } \\
\hline I & S. typhimurium & 4,5,12:i: 1,2 & $\mathrm{~W} \mathrm{LT}_{2}$ & - & $\mathrm{E}, \mathrm{S}$ \\
\hline 2 & S. typhimurium & $1,4,5,12: i: 1,2$ & W $\mathrm{K}_{9}$ & - & S \\
\hline 3 & S. typhimurium & $1,4,5,12: i: 1,2$ & C934.70 & H. faeces, Toulon, 1970 & E \\
\hline 4 & S. typhimurium & $1,4,5,12: \mathrm{i}: 1,2$ & C940.70 & H. blood, Algiers, 1970 & E \\
\hline 5 & S. typhimurium & $I, 4,5,12: \mathrm{i}: 1,2$ & C94I.70 & H. faeces, Mulhouse, 1970 & $\bar{E}$ \\
\hline 6 & S. tsevié & 4.I2:i:e,n, $z_{15}$ & CII4I.72 & H., Togo, 1972 & $\mathrm{E}$ \\
\hline 7 & S. cholerae suis & $6,7: c: 1,5$ & $W_{1348-K_{34}}$ & - & $\mathbf{s}$ \\
\hline 8 & S. cholerae suis & $6,7:-: 1,5$ & WI350-K36 & - & $\mathbf{S}$ \\
\hline 9 & S. cholerae suis & $6,7: c: 1,5$ & $C_{16.67}$ & H. blood, S. Vietnam, 1967 & $\mathrm{E}, \mathrm{S}$ \\
\hline I0 & S. cholerae suis & $6,7: c: 1,5$ & $C_{7} .69$ & Pus, S. Vietnam, I969 & $\mathrm{E}$ \\
\hline II & S. cholerae suis & $6,7: c: 1,5$ & Cio.72 & H. blood, S. Vietnam, 1972 & $\mathrm{E}$ \\
\hline 12 & S. cholerae suis & $6,7: c: 1,5$ & $\mathrm{C} 9.74$ & H. blood, S. Vietnam, r974 & $\bar{E}$ \\
\hline 13 & S. oranienburg & $6,7: \mathrm{m}, \mathrm{t}:-$ & Cro7.69 & H. faeces, Lyon, 1969 & E \\
\hline 14 & S. oranienburg & $6,7: \mathrm{m}, \mathrm{t}:-$ & Cr. 70 & Flour, Algiers, I970 & $\mathrm{E}$ \\
\hline 15 & S. oranienburg & $6,7: \mathrm{m}, \mathrm{t}:-$ & Cro. 70 & H. faeces, Montpellier, 1970 & $\overline{\mathrm{E}}$ \\
\hline 16 & S. oranienburg & $6,7: m, t:-$ & Ci8.70 & H. faeces, Nantes, $1970^{\circ}$ & $\mathrm{E}$ \\
\hline 17 & S. somone & $6,7: \mathbf{z}_{4}, \mathbf{z}_{24}:-$ & C532.69 & Lizard, Dakar, 1969 & $\mathrm{E}, \mathrm{S}$ \\
\hline 18 & S. nanergou & 6,8:g,s,t:- & CI140.72 & H., Togo, 1972 & $\mathrm{E}$ \\
\hline 19 & S. enteritidis & $\mathrm{I}, 9, \mathrm{I2}: \mathrm{g}, \mathrm{m}:-$ & W K64 & 10. & S \\
\hline 20 & S. enteritidis & $\mathrm{I}, 9,12: \mathrm{g}, \mathrm{m}: \mathrm{I}, 7$ & CI91.74 & H. faeces, Abidjan, I974 & E \\
\hline 21 & S. enteritidis & $\mathrm{I}, 9,12: \mathrm{g}, \mathrm{m}: \mathrm{I}, 7$ & C224.74 & H. faeces, Montpellier, 1974 & E \\
\hline 22 & S. enteritidis & $\mathrm{I}, 9,12: \mathrm{g}, \mathrm{m}: \mathrm{I}, 7$ & C243.74 & H. faeces, Lilles, 1974 & E \\
\hline 23 & S. enteritidis & $1,9,12: \mathrm{g}, \mathrm{m}: 1,7$ & C244.74 & H. faeces, La Rochelle, 1974 & $E, S$ \\
\hline 24 & S. dublin & $\mathrm{I}, 9, \mathrm{I} 2, \mathrm{Vi}: \mathrm{g}, \mathrm{p}:-$ & C154.70 & H. faeces, Besançon, 1970 & E \\
\hline 25 & S. dublin & $\mathrm{I}, 9, \mathrm{I} 2, \mathrm{Vi}: \mathrm{g}, \mathrm{p}:-$ & Cis6.70 & H. faeces, St Nazaire, 1970 & E \\
\hline 26 & S. dublin & $\mathrm{I}, 9, \mathrm{I} 2, \mathrm{Vi}: \mathrm{g}, \mathrm{p}:-$ & C157.70 & H. blood, Nice, 1970 & $\mathrm{E}, \mathrm{S}$ \\
\hline 27 & S. gallinarum-pullorum & $1,9,12:-:-$ & C5.72 & Hen, Dakar, 1972 & $\mathrm{E}$ \\
\hline 28 & S. gallinarum-pullorum & 1,9,12:-:- & $\mathrm{C} 9.72$ & Hen, Lyon, 1972 & $\bar{E}$ \\
\hline 29 & S. gallinarum-pullorum & $1,9,12:-:-$ & C13.72 & Hen, Chateau-Thierry, 1972 & E \\
\hline 30 & S. gallinarum-pullorum & 1,9,12:-:- & CI.73 & Guinea, Chateau-Thierry, 1973 & $\mathrm{E}$ \\
\hline $3 \mathbf{I}$ & S. gallinarum-pullorum & $1,9,12:-:-$ & $\mathrm{C}_{4.73}$ & Guinea, Bourges, 1973 & $E, S$ \\
\hline 32 & S. gallinarum-pullorum & I,9, I2:- :- & C4bis. 73 & Bird, Lyon, 1973 & E \\
\hline 33 & S. gallinarum-pullorum & I,9, I 2:- : - & C5.73 & Bird, Paris, 1973 & E \\
\hline 34 & S. anatum & 3,10:e,h: $:, 6$ & $\mathrm{C}_{4.70}$ & H. faeces, Lille, 1970 & $\mathrm{E}$ \\
\hline 35 & S. anatum & 3,I0:e,h:I, 6 & $\mathrm{C} 13.70$ & H. faeces, Tunis, 1970 & $\mathrm{E}$ \\
\hline 36 & S. anatum & 3.Io:e,h:I, 6 & CI 39.70 & H. faeces, Bordeaux, I970 & $\overline{\mathrm{E}}$ \\
\hline 37 & S. anatum & $3,10: e, h: 1,6$ & $C_{141.70}$ & H. faeces, Paris, 1970 & E \\
\hline 38 & S. kande & $\mathrm{r}, 3,19: b: e, n, z_{15}$ & WII34.72 & H., Togo, 1972 & $\mathrm{E}$ \\
\hline 39 & S. $k i b i$ & $16: z_{4}, z_{23}:-$ & $\mathrm{C}_{479.68}$ & Lizard, Ghana, I968 & $\mathrm{E}, \mathrm{S}$ \\
\hline 40 & $S$. mango & $38: \mathrm{k}: \mathrm{I}, 5$ & WII 35.72 & H., Togo, 1972 & $\mathrm{E}$ \\
\hline $4 \mathrm{I}$ & S. waycross & $41: z_{4}, z_{23}:-$ & $\mathrm{C} 237$ & Urine, USA, - & $\mathrm{E}, \mathrm{S}$ \\
\hline \multirow[t]{2}{*}{42} & S. dapango & $47: r: 1,2$ & WI I36.72 &,- 1972 & $\overrightarrow{\mathrm{E}}$ \\
\hline & \multicolumn{5}{|c|}{ Subgenus II (S. salamae group)§ } \\
\hline 43 & Salmonella sp. & $4,12: g, m, t: z_{39}$ & $\mathrm{Cr}_{3} 308.73$ & Meat, S. Africa, 1973 & E \\
\hline 44 & Salmonella sp. & $9,12: 1, z_{28}: e, n, x$ & C14II.74 & Meat, S. Africa, 1974 & $\mathrm{E}, \mathbf{S}$ \\
\hline 45 & Salmonella sp. & $9,46: m, t: e, n, x$ & CII58.72 & Monkey, Africa, 1972 & E \\
\hline 46 & Salmonella sp. & 3,IO: g,m,s,t:- & $C_{1177.72}$ & Meat, Africa, 1972 & $\mathrm{E}, \mathrm{S}$ \\
\hline 47 & Salmonella sp. & $1,13,23: z_{28}:-$ & $C_{1076.72}$ & Lizard, Africa, 1972 & $\mathrm{E}, \mathrm{S}$ \\
\hline 48 & Salmonella sp. & $16: b: z_{39}$ & $\mathrm{C}_{13} \mathrm{I6.73}$ & Tortoise, Great Britain, I973 & $\mathrm{E}$ \\
\hline 49 & Salmonella sp. & $16: z: z_{42}$ & $\mathrm{Cr} 38 \mathrm{I} .73$ & Urine, South Africa, 1973 & E, S \\
\hline 50 & Salmonella sp. & $17: b: z_{8}$ & C1062.72 & Snake, Holland, 1972 & E \\
\hline $5 \mathbf{I}$ & Salmonella sp. & $\mathrm{r}, 40: \mathrm{g}, \mathrm{t}: \mathrm{I}, 5$ & Cr457.74 & Meat, Great Britain, 1974 & $\bar{E}$ \\
\hline 52 & Salmonella sp. & $1,44: e, n, x: 1,6$ & Ci312.73 & Meat, Botswana, 1973 & $\bar{E}$ \\
\hline 53 & Salmonella sp. & $45: \mathrm{z}_{29}: 1,5$ & CI409.74 & Meat, South Africa, I974 & $\mathrm{E}$ \\
\hline 54 & Salmonella sp. & $57: d: I, 5$ & W1061.72 & Lizard, Mulhouse, 1972 & E \\
\hline 55 & Salmonella sp. & $58: z_{10}: z_{6}$ & $C_{1128.72}$ & Lizard, Holland, 1972 & $\mathrm{E}, \mathrm{S}$ \\
\hline \multirow[t]{2}{*}{56} & Salmonella sp. & $58: z_{10}: 1,6$ & WI 449.74 & Reptile, Switzerland, 1974 & $\vec{E}$ \\
\hline & \multicolumn{5}{|c|}{ Subgenus III (S. arizonae)§ } \\
\hline 57 & S. arizonae & $16: k: z_{53}$ & $\mathrm{C}_{2078.64}$ & 一, I964 & $E, S$ \\
\hline 58 & S. arizonae & $16: z_{10}: e, n, x, z_{15}$ & Ciro.68 &,- I968 & $\mathrm{E}$ \\
\hline 59 & S. arizonae & $2 \mathrm{I}: 1, \mathrm{~V}: \mathrm{z}_{57}$ & Wr 1306.73 & Snake, West Germany, I973 & E \\
\hline 60 & S. arizonae & $2 I: i: 1,5,7$ & $\mathrm{C}_{1483.74}$ & Reptile, Israel, I974 & $E, S$ \\
\hline 6I & S. arizonae & $35: z_{29}:-$ & C6680.60.227 & - & E \\
\hline 62 & S. arizonae & $38: z_{52}: z_{53}$ & Wr 305.73 & Snake, South Africa, 1973 & $\mathrm{E}, \mathrm{S}$ \\
\hline 63 & S. arizonae & $47: k: 1,5,7$ & Cro45.72 & Salamander, West Germany, 1972 & \\
\hline 64 & S. arizonae & $5 \mathrm{I}: \mathrm{k}: \mathrm{z}_{35}$ & Ci484.74 & Reptile, Israel, I974 & $E, S$ \\
\hline 65 & S. arizonae & $53: \mathrm{k}: \mathrm{z}$ & W1285.73 & Viper, Switzerland, 1973 & $\mathrm{E}$ \\
\hline
\end{tabular}

* W, Collection of the World Health Organization Collaborating Centre for Reference and Research on Salmonella (L. Le Minor, Institut Pasteur, Paris, France); C, Collection du Centre National des Salmonelles (S. Le Minor, Institut Pasteur, Paris, France). $\uparrow$ H, Human origin.

$\ddagger \mathrm{E}$, Bacteria harvested during the exponential phase; $\mathrm{S}$, bacteria harvested during the stationary phase.

\$ Species designation according to Le Minor et al. (1970). 
Table I (cont.)

\begin{tabular}{|c|c|c|c|c|c|}
\hline Code & Organism & Serotype & $\begin{array}{c}\text { Strain } \\
\text { designation* }\end{array}$ & Origin $\uparrow$, place and date & $\begin{array}{r}\text { Growth‡ } \\
\text { conditions }\end{array}$ \\
\hline $\begin{array}{l}66 \\
67 \\
68 \\
69 \\
70 \\
71\end{array}$ & $\begin{array}{l}\text { S. arizonae } \\
\text { S. arizonae } \\
\text { S. arizonae } \\
\text { S. arizonae } \\
\text { S. arizonae } \\
\text { S. arizonae }\end{array}$ & $\begin{array}{l}60: 1, v: z \\
60: k: z_{35} \\
60: z_{52}: 1,5 \\
61: r: z_{35} \\
6 r: z_{10}: z_{35} \\
65: a: 1,5,7\end{array}$ & $\begin{array}{l}\text { W5716.59 } \\
\text { C2076.64 } \\
\text { WI014.72 } \\
\text { WI } 347.73 \\
\text { WI489.74 } \\
\text { WI501.74 }\end{array}$ & $\begin{array}{l}\text {-, } 1959 \\
\text {-, } 1964 \\
\text { Snake, West Germany, } 1972 \\
\text {-, Atlanta, } 1973 \\
\text { Reptile, West Germany, } 1974 \\
\text { H., Zaire, I974 }\end{array}$ & $\begin{array}{l}E \\
E, S \\
E \\
E, S \\
E \\
E, S\end{array}$ \\
\hline $\begin{array}{l}72 \\
73 \\
74 \\
75 \\
76 \\
77 \\
78 \\
79 \\
80 \\
81 \\
82 \\
83 \\
84 \\
85\end{array}$ & $\begin{array}{l}\text { Subgenus IV } \\
\text { S. mundsburg } \\
\text { Salmonella sp. } \\
\text { S. ochsenzoll } \\
\text { Salmonella sp. } \\
\text { Salmonella sp. } \\
\text { Salmonella sp. } \\
\text { Salmonella sp. } \\
\text { Salmonella sp. } \\
\text { Salmonella sp. } \\
\text { Salmonella sp. } \\
\text { Salmonella sp. } \\
\text { Salmonella } \mathrm{sp} . \\
\text { Salmonella } \mathrm{sp} . \\
\text { Salmonella } \mathrm{sp} .\end{array}$ & $\begin{array}{l}\text { group) } \S \\
\text { I } 1: g, z_{51}:- \\
\text { I }: z_{4}, z_{32}:- \\
16: z_{4}, z_{23}:- \\
18: z_{86}, z_{38}:- \\
21: z_{4}, z_{23}:- \\
38: g, z_{51}:- \\
38: z_{4}, z_{29}:- \\
41: z_{4}, z_{23}:- \\
43: g, z_{51}:- \\
45: g, z_{51}:- \\
48: z_{4}, z_{32}:- \\
50: g, z_{51}:- \\
53: g, z_{51}:- \\
53: z_{4}, z_{23}:-\end{array}$ & 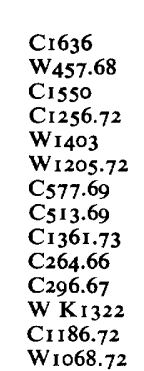 & $\begin{array}{l}\text { Gecko, Madagascar, - } \\
\text {-, Atlanta, I968 } \\
\text { Chameleon, West Germany, - } \\
\text { Snake, Switzerland, } 1972 \\
\text { Reptile, Holland, - } \\
\text { Snake, Switzerland, } 1972 \\
\text { Reptile, West Germany, } 1969 \\
\text { Monkey, U.S.A., 1969 } \\
\text { Python, Zurich, I973 } \\
\text {-, Atlanta, I966 } \\
\text {-, I967 } \\
\text {-, Atlanta, - } \\
\text { H. faeces, Manchester, } 1972 \\
\text { Reptile, U.S.A., I } 972\end{array}$ & $\begin{array}{l}\text { E } \\
\text { E, S } \\
\text { E, S } \\
\text { E, S } \\
\text { E } \\
\text { E } \\
\text { E, S } \\
\text { E } \\
\text { E } \\
\text { E, S } \\
\text { E } \\
\text { E } \\
\text { E, S } \\
\text { E, S }\end{array}$ \\
\hline
\end{tabular}

protein estimation, acrylamide-agarose gel electrophoresis and esterase staining were as described previously (Goullet, 1973, 1975), with the following modifications. Bacteria were grown in L broth (Lennox, 1955) without glucose and harvested during the exponential phase or during the stationary phase (see Table I). They were washed twice in $0.06 \mathrm{M}$ Tris/glycine buffer, $\mathrm{pH} 8 \cdot 7$, before ultrasonic disruption. The $M_{F}$ value, i.e. the distance moved by the esterase band as a percentage of the distance moved by the dye front, was the average obtained from four to six runs. Esterase bands of E. coli KI2 (Goullet, I973) were used as a parallel electrophoretic control. DFP (Calbiochem) was used at $\mathrm{IO}^{-6}$ to $\mathrm{IO}^{-3} \mathrm{M}$.

\section{RESULTS}

\section{Esterase band differentiation by naphthyl esters}

Reproducible esterase patterns were obtained with the four synthetic substrates. All bacterial strains analysed gave between three and six anodal esterase bands which varied in sharpness and colour intensity. Four principal esterase bands, designated as $E_{1}, E_{2}, E_{3}$ and $\mathrm{E}_{4}$ in order of decreasing electrophoretic mobility, were defined (Fig. I $a$ ). Bands $\mathrm{E}_{1}$ and $E_{4}$ hydrolysed $\alpha$-naphthyl acetate. The $E_{1}$ band remained active in the presence of $\mathrm{IO}^{-4} \mathrm{M}$-DFP whereas the $\mathrm{E}_{4}$ band was inhibited by $\mathrm{IO}^{-5} \mathrm{M}-\mathrm{DFP}$. The $\mathrm{E}_{2}$ band hydrolysed $\beta$-naphthyl acetate but was not affected by $10^{-3} \mathrm{M}$-DFP. The $\mathrm{E}_{3}$ band hydrolysed both $\alpha$ and $\beta$-naphthyl esters but produced a darker stain with the $\alpha$-forms; it was inhibited by $\mathrm{IO}^{-6} \mathrm{M}$-DFP. These four esterase bands were inactivated by $\mathrm{Io}$ min treatment at $60^{\circ} \mathrm{C}$. The $\mathrm{E}_{2}$ band and, in some cases, the $\mathrm{E}_{3}$ band were more pronounced in bacteria harvested during the stationary phase. In addition, two minor bands reacting with $\beta$-naphthyl acetate occupied the extreme positions of the zymogram: the faster band $(\mathrm{F}), M_{F} \approx 95$, was very faint and was inactivated by treatment at $60^{\circ} \mathrm{C}$, the slower one $(\mathrm{S}), M_{F} \approx \mathrm{II}$, was diffuse and remained active at this temperature.

All $M_{F}$ values were approximate because of variations between different runs. However, electrophoretic relationships could be established between the strains by numerous replicate assays comparing esterase bands in adjacent positions on the same gel. 


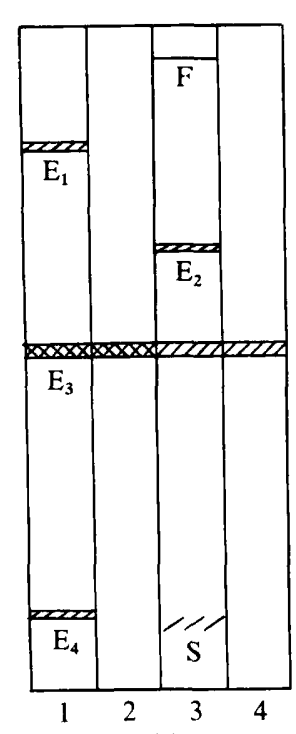

(a)

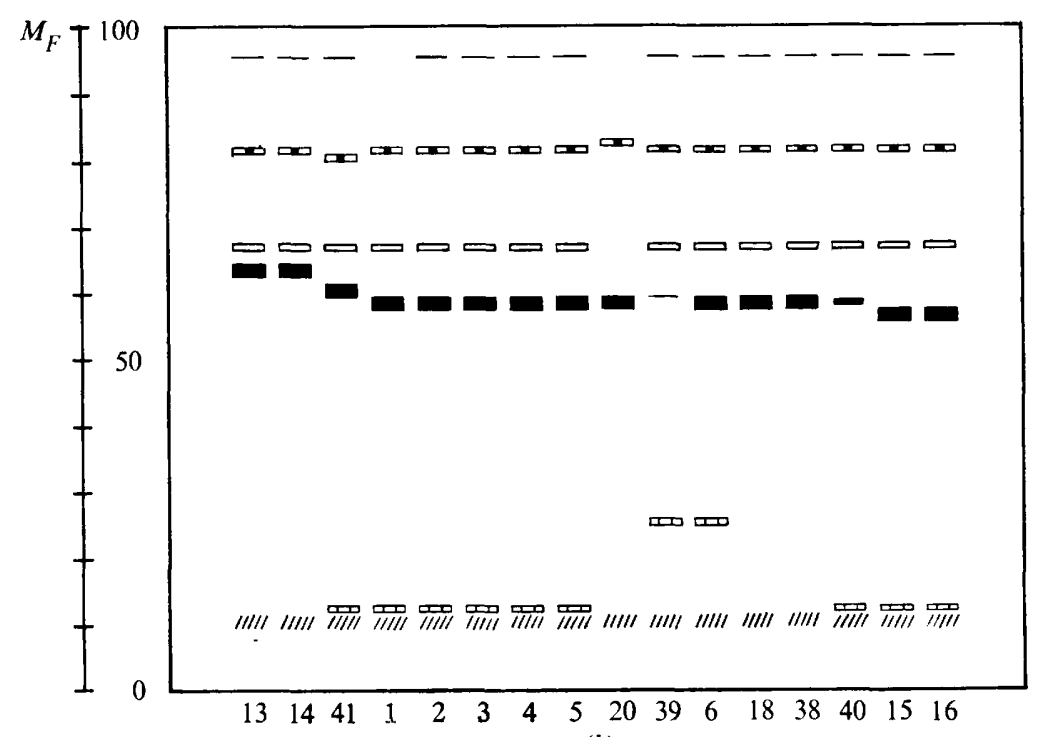

(b)

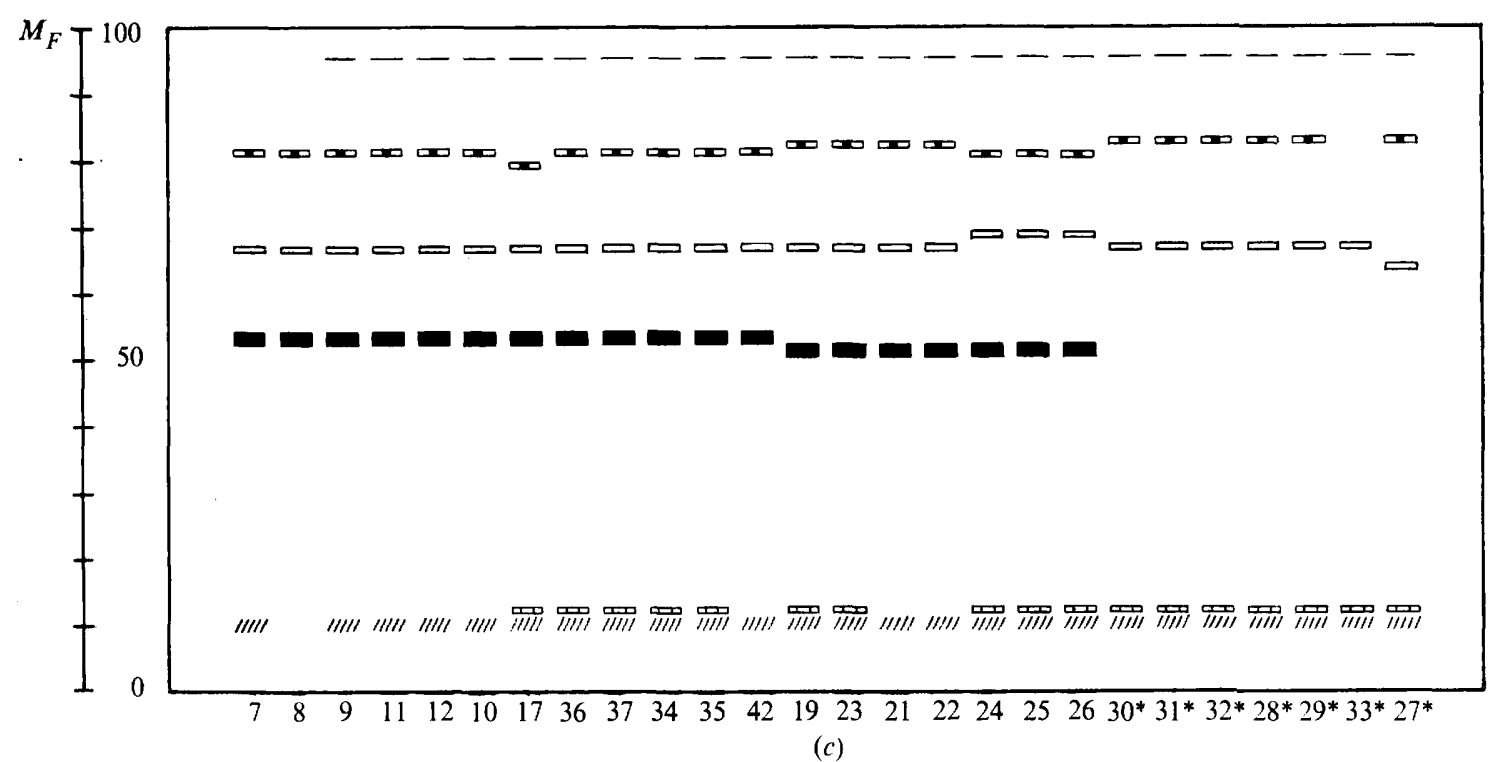

Fig. I. Salmonella subgenus I. (a) Schematic representation of mobility and activity of esterase bands (strain 23). Horizontal slab acrylamide-agarose gel electrophoresis was performed using $7 \%(\mathrm{w} / \mathrm{v})$ acrylamide and discontinuous Tris/glycine buffer, $\mathrm{pH} 8.7$ (Uriel, 1966). Esterase activity was revealed by the method of Uriel (196I). Substrates used were: $1, \alpha$-naphthyl acetate; $2, \alpha$ naphthyl butyrate; $3, \beta$-naphthyl acetate; $4, \beta$-naphthyl butyrate. Relative intensity of staining: $\square>\square[D>\square Z>Z$. (b), (c) Esterase patterns of the 42 strains arranged in order of decreasing mobility of $E_{3}$ esterase bands. $\square \square, E_{1}$ band; $\square, E_{2}$ band; $\square, E_{3}$ band; $\amalg, \mathrm{E}_{4}$ band; - - , fast band; /III/, slow band. Asterisks indicate S. gallinarum-pullorum strains. 


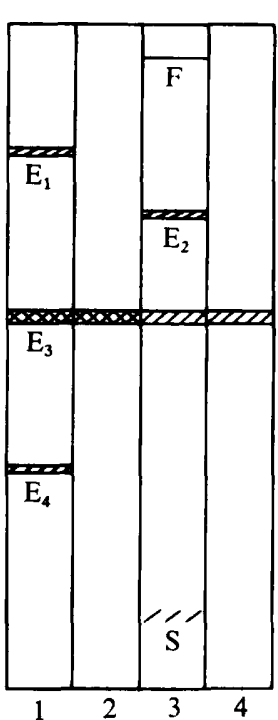

(a)

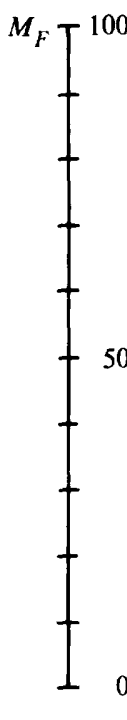

.

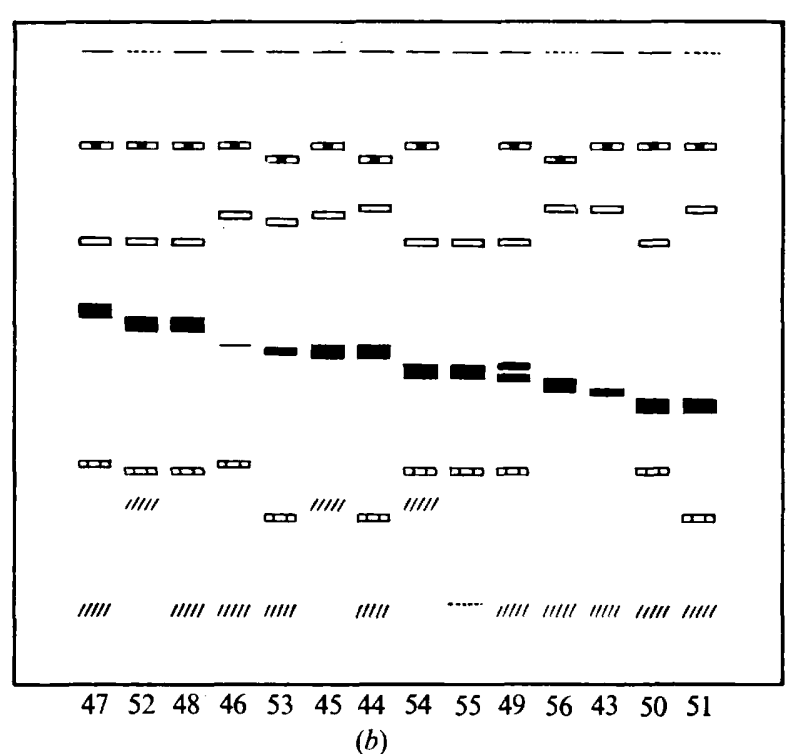

(b)

Fig. 2. Salmonella subgenus II. (a) Schematic representation of mobility and activity of esterase bands (strain 47). (b) Esterase patterns of the 14 strains arranged in order of decreasing mobility of $\mathrm{E}_{3}$ esterase bands. Experimental conditions, relative intensity of staining and key as in legend to Fig. 1.

\section{Salmonella subgenus I (S. kauffmannii)}

The $E_{3}$ band of strains of subgenus I was clearly visible in most of the strains but very faint in strain 39 and undetectable in $S$. gallinarum-pullorum strains (Fig. I $b, c$ ). Its mobility ranged from $M_{F} \approx 62$ to $M_{F} \approx 52$. The $\mathrm{E}_{4}$ band was very close to the $\mathrm{S}$ band when $7 \%$ acrylamide was used but became distinct at $5 \%$ acrylamide. In some strains, it was not detected.

\section{Salmonella subgenus II (S. salamae)}

The esterase bands from strains of this subgenus had essentially the same hydrolysing activity, and DFP and heat sensitivity as those of subgenus I (Fig. $2 a$ ). The $\mathrm{E}_{2}$ and $\mathrm{E}_{3}$ bands exhibited electrophoretic heterogeneity (Fig. $2 b$ ). The $\mathrm{E}_{3}$ band was seen in all strains though it was very faint in strain 46 . The $E_{4}$ band migrated faster than the corresponding band of subgenus I. The differences in esterase band mobilities enabled each of the I4 strains analysed to be distinguished.

\section{Salmonella subgenus III (S. arizonae)}

The strains of this subgenus also gave six bands but the $E_{4}$ band was located between bands $\mathrm{E}_{2}$ and $\mathrm{E}_{3}$ (Fig. $3 a$ ). The $\mathrm{E}_{3}$ band was generally less stained and migrated slower than the corresponding bands of subgenera I and II (see Figs I $a, 2 a$ ). In some strains, the $E_{3}$ band or the $E_{4}$ band was not detected.

\section{Salmonella subgenus $I V(S$. houtenae)}

Bands $\mathrm{E}_{1}, \mathrm{E}_{2}$ and $\mathrm{E}_{3}$ of subgenus IV (Fig. $4 a$ ) had similar characteristics to those of subgenus III. The $\mathrm{E}_{4}$ band was not detected. The $\mathrm{E}_{3}$ band mobility varied from $M_{F} \approx 40$ to 


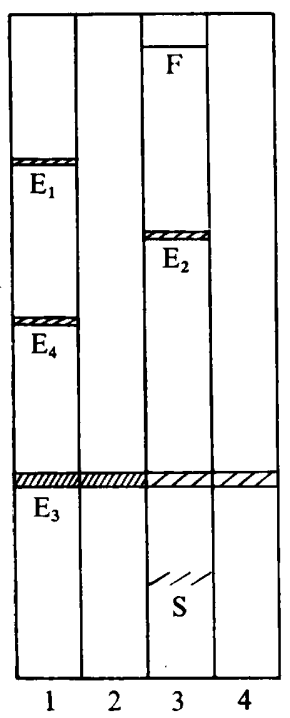

(a)

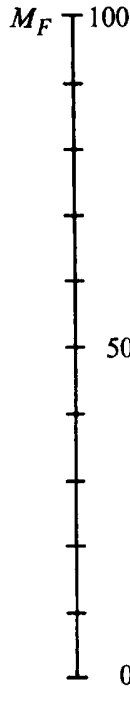

$\begin{array}{llllll}61 & 63 & 68 & 70 & 66 & 67\end{array}$

Fig. 3. Salmonella subgenus III. (a) Schematic representation of mobility and activity of esterase bands (strain 67). (b) Esterase patterns of the 15 strains arranged in order of decreasing mobility of $E_{3}$ esterase bands. Experimental conditions, relative intensity of staining and key as in legend to Fig. I.

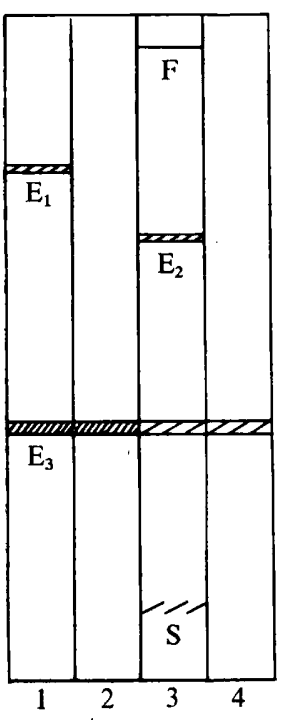

(a)

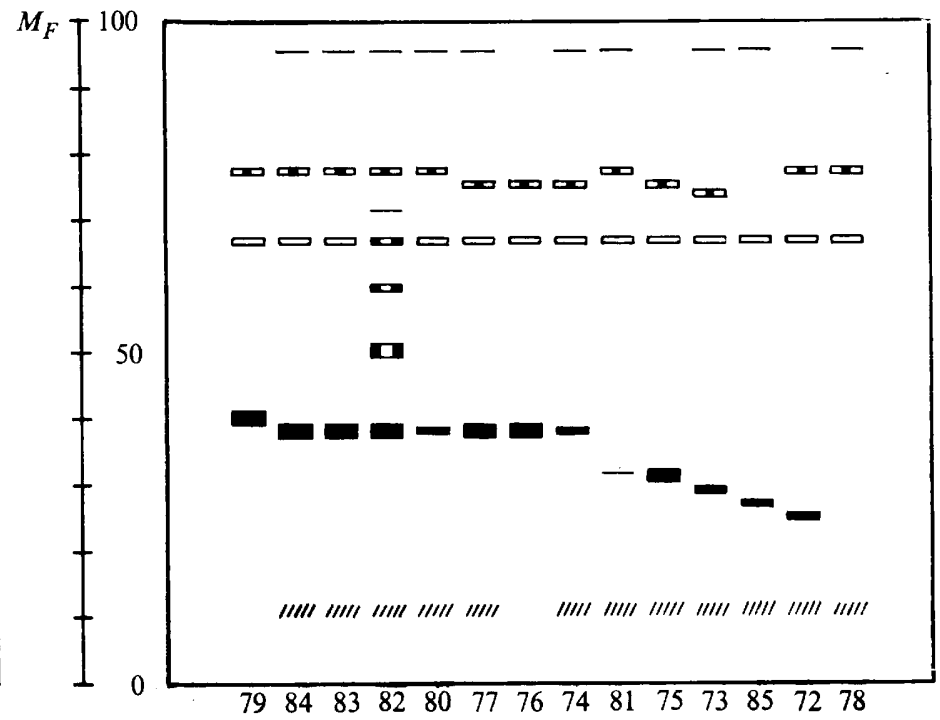

(b)

Fig. 4. Salmonella subgenus IV. (a) Schematic representation of mobility and activity of esterase bands (strain 84). (b) Esterase patterns of the 14 strains arranged in order of decreasing mobility of $E_{3}$ esterase bands. Experimental conditions, relative intensity of staining and key as in legend to Fig. I. Unusual bands hydrolysing $\alpha$ - and $\beta$-naphthyl acetates are indicated by $\square$. 


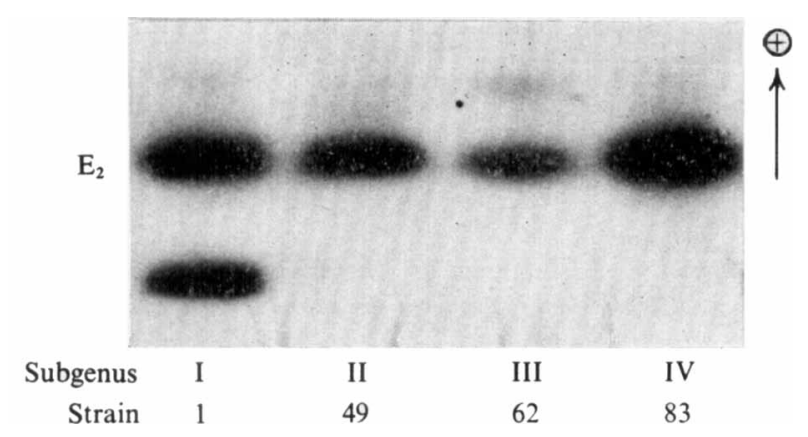

Fig. 5. Migration of $\mathrm{E}_{2}$ esterase bands from strains of different subgenera. Enzyme activity was demonstrated with $\beta$-naphthyl acetate as substrate.

Table 2. $M_{F}$ values of esterase bands in the four subgenera of Salmonella

Mean $M_{F}$ values are given together with the standard deviation. Sample sizes are given in parentheses

\begin{tabular}{|c|c|c|c|c|}
\hline Band & Subgenus I & Subgenus II & Subgenus III & Subgenus IV \\
\hline $\mathbf{E}_{1}$ & $8 I \cdot 34 \pm 0.85(4 I)$ & $80.54 \pm 0.87$ (13) & $78.0 \pm 0.0 \quad(\mathrm{II})$ & $76 \cdot 15 \pm I \cdot 14$ (I3) \\
\hline $\mathrm{E}_{2}$ & $67.07 \pm 0.72(4 \mathrm{I})$ & $69 \cdot 21 \pm 2 \cdot 35(14)$ & $67.0 \pm 1.96(15)$ & $67.0 \pm 0.0 \quad$ (13) \\
\hline $\mathrm{E}_{3}$ & $55 \cdot 14 \pm 3 \cdot 51$ & $48 \cdot 50 \pm 4 \cdot 41$ (I 4$)$ & $32 \cdot 46 \pm 3.84$ (13) & $34.61 \pm 5.09$ (13) \\
\hline$E_{4}$ & $12.92 \pm 3.40(28)$ & $30 \cdot 27 \pm 3 \cdot 40$ (II) & $55 \cdot 85 \pm 4.67$ (I4) & - \\
\hline
\end{tabular}

$M_{F} \approx 25$ (Fig. 4 b). It was very faint in strain $8 \mathrm{I}$ and not detected in strain 78 . Bands $\mathrm{E}_{2}$ and $S$ showed electrophoretic uniformity with respect to one another. The $E_{2}$ band mobility was identical to that of numerous strains of subgenera I, II and III. Figure 5 illustrates this electrophoretic relatedness between the four subgenera. Strain 82 exhibited a set of unusual bands hydrolysing acetate esters but not butyrate esters. Strains $74,76,78,79$ and 85 showed no special esterase relationships with strains 39 and $4 \mathrm{I}$ of subgenus I though all have the same flagellar antigens: $z_{4}, z_{23}$ (see Table 1 ).

\section{DISCUSSION}

Six esterase bands differing in their activity towards naphthyl esters, sensitivity to DFP and electrophoretic mobility were found in extracts of Salmonella. The $M_{F}$ values of the $E_{1}, E_{2}, E_{3}$ and $E_{4}$ bands in the four subgenera are compared in Table 2. Bands $E_{1}$ and $E_{2}$ showed little variation in mobility. In contrast bands $\mathrm{E}_{3}$ and $\mathrm{E}_{4}$ showed considerable electrophoretic variability. The mobility of $E_{3}$ decreased from subgenus I to subgenera III and IV whereas the mobility of $E_{4}$ increased from subgenus I to subgenus III. The two minor bands $\mathrm{F}$ and $\mathrm{S}$ observed in the four subgenera are electrophoretically distinct from the corresponding bands of E. coli (Goullet, 1973).

With respect to the characteristics of the various esterase bands, all Salmonella strains appeared to be closely related, which is consistent with the 70 to $87 \%$ of DNA reassociation between strains belonging to different subgenera (Crosa et al., 1973; Stoleru, Le Minor \& Lhéritier, 1976). However, the divergences in the electrophoretic distribution of bands $E_{3}$ and $E_{4}$ observed between the four biochemically-defined clusters, although far less striking than those observed between the Proteus species (Goullet, 1975) and between L. malonatica and L. amalonatica (Goullet \& Richard, 1977), are sufficient to recognize the subgenera of most of the Salmonella strains analysed. 
The author thanks Madame Nicole Jean and Mademoiselle Catherine Lamesch for technical assistance. This work was supported by grants from the Université de Paris VII and from the Institut National de la Santé et de la Recherche Médicale (no. 75.I.I I4.I).

\section{REFERENCES}

Bascomb, S., Lapage, S. P., CurTis, A. \& Willcox, W. R. (1973). Identification of bacteria by computer: identification of reference strains. Journal of General Microbiology 77, 29I-31 5.

Crosa, J. H., Brenner, D. J., Ewing, W. H. \& Falkow, S. (I973). Molecular relationships among the Salmonelleae. Journal of Bacteriology Ir5, 307-315.

EwING, W. H. (1972). The nomenclature of Salmonella, its usage and definitions for the three species. Canadian Journal of Microbiology 18, 1629-1637.

Goullet, РH. (1973). An esterase zymogram of Escherichia coli. Journal of General Microbiology 77, 27-35.

Goullet, PH. (1975). Esterase zymograms of Proteus and Providencia. Journal of General Microbiology 87, 97-106.

Goullet, PH. \& Richard, C. (1977). Distinctive electrophoretic patterns of esterases from Levinea malonatica, Levinea amalonatica and Citrobacter. Journal of General Microbiology 98, 543-549.

Johnson, R., Colwell, R. R., Sakazaki, R. \& Tamura, K. (1975). Numerical taxonomy study of the Enterobacteriaceae. International Journal of Systematic Bacteriology 25, I 2-37.

Kauffmann, F. (1963). Zur Differentialdiagnose der Salmonella Sub-genera I, II and III. Acta pathologica et microbiologica scandinavica 58, I09-1 13.

KaUfFManN, F. (1965). Weitere Salmonella Species der Sub-genera II, III and IV. Acta pathologica et microbiologica scandinavica 64, 367-372.

Kauffmann, F. (1975). Classification of Bacteria: A Realistic Scheme with Special Reference to the Classification of Salmonella and Escherichia Species. Copenhagen, Denmark: Munksgaard.

Le Minor, L. \& RHODE, R. (1974). Genus IV, Salmonella. In Bergey's Manual of Determinative Bacteriology, 8th edn, pp. 298-31 8. Edited by R. E. Buchanan and N. E. Gibbons. Baltimore: Williams \& Wilkins.

Le Minor, L., RHODE, R. \& TAYLOR, J. (1970). Nomenclature des Salmonella. Annales de l'Institut Pasteur, Paris I19, 206-210.

LENNOX, E. S. (1955). Transduction of linked genetic characters of the host by bacteriophage Pi. Virology I, 190-206.

Stoleru, G. H., Le MinOR, L. \& LhÉRITIER, A. M. (1976). Polynucleotide sequence divergence among strains of Salmonella sub-genus IV and closely related organisms. Annales de Microbiologie (Institut Pasteur) 127A, 477-486.

VÉRON, M. \& LE MINOR, L. (1975). Nutrition et taxonomie des Enterobacteriaceae et bactéries voisines. III. Caractères nutritionnels et différenciation des groupes taxonomiques. Annales de Microbiologie (Institut Pasteur) I26B, 125-147.

URIEL, J. (1961). Caractérisation des cholinestérases et d'autres estérases carboxyliques après électrophorèse et immunoélectrophorèse en gélose (application à l'étude des estérases du sérum humain normal). Annales de l'Institut Pasteur Io1, 104-I 19.

URIEL, J. (I966). Méthode d'électrophorèse dans des gels d'acrylamide-agarose. Bulletin de la Société de chimie biologique 48, 969-982. 